\title{
A SPEECH ACT ANALYSIS OF TEACHER TALK IN AN EFL CLASSROOM
}

\author{
Sri Meiweni Basra ${ }^{1}$, Luthfiyatun Thoyyibah ${ }^{2}$ \\ English Education Program, Indonesia University of Education \\ srimeiweni.basra@gmail.com, luthfiyatun20@gmail.com
}

First draft received: 30 May 2017

Final proof received: 14 August 2017

\begin{abstract}
The inappropriate use of speech act in EFL classroom may lead to misunderstanding due to the distinct cultures between the origin of language and the users. The purposes of the research are to find out speech act classification mostly used by an EFL teacher while teaching, the reason of why certain classification was preferred and the implication of the selected speech act classification toward the teaching and learning process. This research is a case study research involving an English teacher teaching an EFL class. The study uses Searle's taxonomy of speech act classification as the instrument. The findings of the research show the frequency of each classification found as the following: $70 \%$ for directives, $21 \%$ for representative, $6 \%$ for expressive and $3 \%$ for commissive. Directive speech acts are used mostly by the teacher because the teacher adopts the principle of Communicative Language Teaching. The use of directive speech act apparently make implication towards the improvement of the students' productive skills. The study concludes that the choice of speech acts classification determine the teaching approach and vice versa. It is recommended for English teachers wishing to help students to achieve communicative competence to use more directive speech acts.
\end{abstract}

Keywords: Speech act; directive; representative; expressive; declarative.

To cite this paper (in APA style):

Basra, S. M., \& Thoyyibah, L. (2017). A speech act analysis of teacher talk in an EFL classroom. International Journal of Education, 10(1), 73-81. doi: http://dx.doi.org/10.17509/ije.v10i1.6848

\section{INTRODUCTION}

The success in running English teaching and learning process in the classroom depends on various factors, one of which is the language used by the teacher. Celce-Murcia (2000) pointed out that language use applied in the classroom affect students' process and progress of learning. In the matter of EFL (English as a Foreign Language) teaching in Indonesian context, in which the teachers are not the natives of English, running EFL teaching and learning is troubling in terms of delivering the lesson using English and getting students to understand the instruction mentioned using the language.

However, there are problems related to the use of English (as a foreign language) in the classroom. Nuraini (2015) in her research mentioned a problem in the use of speech acts in English classroom. She argued that the use of speech acts in Indonesian EFL class leads to a misunderstanding due to the inappropriate use of the speech acts uttered. Students may have different interpretations of a simple utterance said by the teacher. This is caused by the failure of using IFIDs (Illocutionary Force Indicating Devices) or deciding to use either direct or indirect speech acts in certain situation. The culture contributes to different styles of language use applied in making utterances. For instance, Seifoori and Emadi (2015) found out that Americans and Persians have different ways in complimenting. This is related to the way they see the culture, the values in it comprising social distance, status, and the belief of how to reach for politeness or directness in communication.

This study is aimed at investigating classroom speech acts performed by an English teacher in terms of speech acts classification determined by the theory of John R. Searle (1999). The study hopefully fills the gap of research regarding speech acts classification analysis which has been conducted previously mostly by focusing on the analysis of political speeches.

The British philosopher J.L Austin was the first one coming up with the theory of speech acts. The work of Austin and his theories about speech acts were further developed by an American philosopher John R. Searle. Yule (1996) stated that speech acts are often associated with the term of illocutionary acts. Both terms, speech acts and illocutionary acts, have the same idea that there is communicative force behind the performance of an utterance.

Speech acts or illocutionary acts have classifications. Different scholars develop their own 
taxonomy of speech acts classification. One of the well-known classifications comes from the work of John R. Searle. Searle (1999) categorized five different types of illocutionary acts; assertive force, directive force, commissive force, expressive force, and declarative force.

Enyi (2016) concluded from his study that different speech acts have different perlocutionary effects. He also said that deciding to use certain speech acts classification is affected by certain factors. For example, government officials giving political speeches may decide to use more assertive, expressive, and commissive acts to gain people attention and persuade people in order to achieve their goals.

In the case of speech acts in political speeches, Hashim (2015) found that commissive speech act takes the highest frequency of speech acts uttered in two political speeches (John Kerry's in 2004 Presidential Campaign and George Bush' in 2004 Inaugural adress). It is then followed by assertive, directive, and expessive. The finding reflects that the overall speech act uttered in both speeches analyzed is aimed at convincing the audience to take their sides.

In line with Hashim (2015), Enyi (2016) also found a representation of the act of convincing people through President Mohammadu Buhari's Maiden Coup Address of January 1st 1984 and his Inaugural Address on May $29^{\text {th }} 2015$ speeches. Commissive takes $35 \%$ and $54 \%$ for the former and the latter speech and is followed by assertive (32\% and 35\%). Vows, promisses, and pledges are expressed to gain citizens'attention to vote for him.

Unlike political speeches which emphasize more comissive speech acts, advertisements take emphasis on another kind of speech act, that is directive speech act. Chiluwa (2007) discovered directive speech acts are used dominantly in $95 \%$ of popular soft drink advertisements between 2000 and 2006. This aims to get audiences to buy the products advertised.

Similarly, Facebook status also has its own type of speech acts. Ilyas and Khushi (2012) conducted a speech act analysis on Facebook status updates from 60 males and females. The analysis reveals that expressive speech acts take the biggest portion of all speech acts types in Searle's taxonomy due to the fact that Facebook is mostly used to express feelings and ideas.

The previous research reveals that each purpose of communication has its own pragmatic characteristics. Political speeches are characterized by commissive speech acts, advertisments emphasize the use of directive speech acts, and Facebook status updates frequently carry more expressive speech acts. This matter goes the same in the EFL teaching and learning process. Teachers in classroom also decide which speech acts classification to use to achieve their goal of teaching and learning. The decision of using certain speech acts in the teaching process in classroom may result on certain impacts.
Based on the perspectives elaborated earlier, this study is conducted to investigate the classification of speech act used by an English teacher in EFL classrooms in Indonesian context.

Therefore, there are three objectives of this study. The first one is to find out which classification of speech act is mostly used by a teacher in teaching an EFL classroom. The second objective is finding out the reasons why certain classification of speech act is preferred by the teacher. The third one is figuring out the implication of using the preferred classification of speech act towards either the teaching process or students' achievement.

This study, theoretically, contributes to fill the gap of speech act research on the matter of speech acts or illocutionary acts classification. Most studies commonly analyze political speeches, advertisement, and the strategy of performing certain speech acts (such as complimenting, apologizing, refusing and so on). Therefore, this study hopefully enriches the literature of the study of speech acts used by teacher in EFL classrooms in Indonesian context.

Besides, for English teachers, this study also contributes ideas and insights on how the choice of language function (speech act classification) may affect the classroom process, including the students themselves, their score, or their learning progress. Finally, this study is expected to encourage teachers to improve their quality of teaching by first starting to reflect and evaluate on how they use illocutionary acts in their teaching process.

\section{REVIEW OF THE LITERATURE Teacher Talk}

Teacher talk is the talk that a teacher does in the teaching and learning process. Lei (2009) stated that good communication in the teaching and learning process depends on a good and effective teacher talk. Apparently, Harmer (2007) implied that students learn from the teacher talk. That is the reason why the teachers are expected to know how to talk to students and adjust the language that they use because teacher talk gives a chance for students to hear the language which they more or less understand.

Communicative teacher talk has some features according to Lei (2009). Some of them are referential questions and content feedback. Referential questions are questions in which the teacher genuinely does not know the answer of. By posing such questions, the teacher engages students to answer the question and talk. Content feedback means the teacher comments on what students are saying.

Harmer (2007) pointed out that too much teacher talk can make students lose their chance to talk, and he actually stated that a good teacher maximizes time for students to talk and minimize time for him/her to talk. However, a study from Sadeghi, Ansari, and Rahmani (2015) proves that appropriate teacher talk brings positive effect on students' engagement and 


\section{Sri Meiweni Basra - Luthfiyatun Thoyyibah | A Speech Act Analysis of Teacher Talk in an EFL Classroom}

attitudes. Appropriate teacher talk can contribute either to the presence of politeness or directness in teaching which will impact on the teaching process and students.

\section{Pragmatics}

Pragmatics is a broad term in the field of linguistics. Akinwotu (2013) simply defined pragmatics as the study of language in use. Mey (2001) pointed out that pragmatics is characterized by the idea that language is used by its user and the use of language depends on norms, rules and beliefs exist in the community where the users live. This means that Pragmatics is a branch of linguistics knowledge which encompasses the blending of the knowledge of morphology, phonology, syntax and even semantics.

Pragmatics has something to do with the fact that users use language in context and that language is restricted to culture. Grundy (2008) stated that the meaning and the intention of utterances uttered by users are determined by the existence of a context. $\mathrm{He}$ also added that culture and context play roles in communication. It is because without contexts, a hearer does not understand what a speaker intends to say by his/her words. Grundy's emphasis clearly points out that culture cannot be separated from the language when users communicate. Every country does not always share the same culture. Recognizing the rule, habits, and beliefs of each culture counts in achieving understandable and accepted utterances when one wishes to communicate in a particular language existing in a particular culture.

\section{Speech acts}

The theories about speech acts can be traced back from the works of J.L Austin in the lectures he delivered, which later on were codified in a book called How to Do Things with Words. The book was published in 1962 after his death. Austin (1962) stated that sometimes, when people utter an utterance, it is not always to describe something. Instead, by uttering utterances, they actually do something.

Speech acts are those acts of making statement or question, giving commands or order, refusing, complimenting, apologizing, and etc. Yule (1996) acknowledged that by performing speech acts, people do not merely say something using the language out of the blue. Instead, they have intention and force behind the utterances they utter and those utterances may affect the behavior of the hearer.

There are three categories or dimensions of speech acts. Grundy (2008) explained that when people say something, they may involve the three dimensions, which are locutionary acts, illocutionary acts, and perlocutionary acts.

a. Locutionary acts

Locutionary acts are basic utterances uttered by people shaped in the right grammar and understandable vocabulary. From the examples given by Yule (1996) in his book, it is clear that he tried to say that one of the requirements to meet in performing locutionary acts is that both the speaker and the hearer share the same language; otherwise, there will be misunderstanding or the meaning intended will not be understood by the hearer.

b. Illocutionary acts

Yule (1996) stated that the term "illocutionary acts" is often closely associated with the term speech act. When people have communicative force in saying an utterance, it means that they are performing an illocutionary act. For example, saying "put it out" may have a different kind of force behind that. The speaker may say that because he tries to stop a lady smoking in a smoke free area, or he sees a window curtain is on fire. Having intention to say particular utterances contribute to the idea of illocutionary acts.

\section{c. Perlocutionary acts}

People (speakers) perform perlocutionary acts by expecting to affect other people's (hearers') behavior. Affecting behavior does not necessarily mean getting the hearer to do physical movements; it also deals with the change of thought or habit of the hearer. This statement is in line with Yule (1996) who pointed out that perlocutionary acts bring the-so-called perlocutionary effect. One of the examples illustrating this situation is when a speaker is feeling sad of being left out, he says "I am useless" to a friend. By hearing the utterance, the hearer is affected and feels sorry. Felling sorry is the effect of the perlocutionary acts of the utterance "I am useless".

The term "speech act" comprises many theories under it. It includes the theory of performative verbs, IFIDs (Illocutionary Force Indicating Devices, felicity conditions, speech acts classification, direct and indirect speech acts, speech events, and so on.

\section{Speech acts classification}

A number of different scholars revealed different speech acts classifications which actually were originated from Austin's. Oluremi (2016) pointed out that Austin's speech acts classifications include verdictives, exercitives, commissives, behabitives, and expositives. However, a popular American Philosopher, John R. Searle, extended the ideas, making his taxonomy a reference or framework of speech act classification used by many researchers conducting research on speech act classification.

Searle (1999) categorized five different types of illocutionary acts; assertive force, directive force, commissive force, expressive force, and declarative force. Yule (1996) represented a table of the five speech acts classification based on the theory of Searle. 
Table 1. Speech Act Classification

\begin{tabular}{lll}
\hline Speech act type & Direction of fit & S = Speaker; $\mathbf{X}=$ Situation \\
\hline Declarative & Words change the world & S causes X \\
\hline Assertive & Make words fit the world & S believes X \\
\hline Expressive & Make words fit the world & S feels X \\
\hline Directive & Make the world fit words & S wants X \\
\hline Commissive & Make the world fit words & S intends X \\
\hline
\end{tabular}

a. Declarative force

Declarative force has a principle that words change the world. It means that speech act uttered by a speaker changes the world or situation. It is illustrated by the sentences below.

[1] Police officer: You are under-arrest!

When a police officer says utterance [1] to a person doing a crime, the utterance changes the situation of the criminal. From the status of a free man, the person doing the crime is put in jail. However, if the utterance [1] is uttered by a teacher to a student, the utterance does not make any difference or change whatsoever the student because the ones who have the rights to say the utterance [1] are only police officers.

b. Assertive force

Making words fit the world means that speech acts with assertive force is used to state what the speaker believes to be the case or not the case. Yule (1996) said that assertive force is used to represent the world as the speaker believes it is. Below are the examples of speech acts with assertive force.

[2] The earth is flat

[3] Roses smell good

c. Expressive force

As shown by the table 1 , by performing speech acts with expressive force, speaker wants to show what he/she feels about particular situations. Expressive force expresses psychological state such as likes and dislikes, joy, sorrow, pain, and many others. [4] and [5] are the examples.

[4] I am really sorry.

[5] Congratulation

\section{d. Directive force}

Performing speech acts with directive force means that the speaker wants to get someone to do something. Giving commands and orders are some examples of speech acts with directive force. [6] is one of the examples.

[6] Go away!

\section{e. Commissive force}

Commissive force in speech acts shows speaker's intention. Yule (1996) stated that speakers use commissive force to express promises, threats, refusals, or pledges. It has something to do with showing speaker's intention in the future as shown in [7].

[7] I promise to buy you ice cream after school.

\section{METHOD}

\section{Research Design}

Since this study is aimed at investigating classroom speech acts performed by an English teacher in terms of speech acts classification determined by the theory of John R. Searle, this study is categorized under the principle of qualitative research design, specifically, a case study. Geertz in Cohen (2007) pointed out that a case study has something to do with investigating how a phenomenon is like by looking closely at the case and providing a thick description explaining participants' thoughts about and feelings for a situation. A case study is a perfect fit for this study, as this study attempts to reveal how speech acts are used by a teacher of English. This study elaborates the case and findings as they really are without manipulations.

\section{Participants}

An English teacher participated in this study. She comes from West Java, Indonesia. She is 25 years old. She teaches in a well-known English course in Bandung and has been teaching for about three years. The level of students she teaches varies from A1 level to C1 level using the level of CEFR (Common European Framework of Reference) based on Introductory Guide to the Common European Framework of Reference for English Language Teachers (2013).

The teacher was chosen for some reasons. First of all, she teaches in the classroom using full English. Second, the exposure of English she has is good enough as the place where she teaches or works regulates people to speak English both for teachers and students. Third, with a score TOEFL of 602 , she is able to teach almost all levels of students in the English course.

The class was chosen based on the highest average score among all in the English course in the level of B1 in CEFR. Students' ages in that B1 level class are varied, starting from 16 years old to 22 years old. 


\section{Sri Meiweni Basra - Luthfiyatun Thoyyibah |A Speech Act Analysis of Teacher Talk in an EFL Classroom}

\section{Material}

There are three types of data which were collected. First, a full-length video of a teaching and learning process in one meeting. The video is 1 hour, 26 minutes and 34 seconds in length. Second, teacher's interview and the last one is the documents of students' scores.

\section{Procedure}

In the process of collecting the data, observation was conducted. The data to be analyzed were collected by videotaping the process of teaching and learning. Next, the teacher was interviewed to confirm some cases of speech acts happening in the classroom while she was teaching. In addition, the document of students' scores was collected from the teacher.

Before analyzing the data and finding out the speech act classification, the videotaped-data were transcribed. The speech acts, performed by the teacher while teaching in the classroom, were subsequently analyzed within the framework of the five major classifications of speech acts developed by Searle: assertives, directives, commissives, expressives, declaratives.

To determine the sentences to be categorized into Searle's speech act classification, a framework was developed based on speech act word clues or characteristics proposed by Qadir and Riloff (2011), who further developed speech act word clues listed by Searle (1976). Next, the percentage of each speech acts classification was counted and interpretation was drawn from the findings and was descriptively described.

\section{FINDINGS AND DISCUSSION}

This section presents the findings and their interpretation, organized in terms of the sequence of the research questions.

\section{Classification of Speech Acts Used by the Teacher to Students in an EFL Classroom Declarations (0\%)}

It is found that there are only four speech act classifications used by the teacher to teach in the classroom. The teacher excludes the use of declarative speech act classification. It is obviously due to the nature of declarative speech act, in which Yule (1996) explained that declarative speech act changes the world of the hearer via utterances uttered by a speaker. The speaker needs to have a special institutional role to change the world of the hearer. The changing world of the hearer means that the situation which is changed from him/her/them caused by a speaker is not easy to be avoided or broken or left. The change of situation caused by a speaker to a hearer stays longer; for example, when a priest declares somebody to be somebody else's wife or husband. A mother or a doctor is not legalized to marry a couple. To sum up, the teacher does not use declarative speech act in her teaching.

\section{Representatives (21\%)}

Out of 673 utterances, it is found that 141 of them have the characteristics of representative speech acts. By developing Searle's speech act word clue lists, Qadir and Riloff (2011) came up with a number of representative speech act word clues. The list includes the act of hypothesizing, insisting, boasting, complaining, concluding, deducing, diagnosing, claiming, assuming, and suspecting.

The finding related to representative speech acts obtained from the data includes the act of concluding and repeating students' answer to make sure or conclude what is said as what it is. Some samples from the data are presented in the table below.

Table 2. Representative Speech Act

\begin{tabular}{ll}
\hline Utterance & $\begin{array}{l}\text { Representative } \\
\text { act categories }\end{array}$ \\
\hline "yeah, so 4" & Concluding \\
(actually it means "yes, so there are four questions all together") & Claiming \\
\hline "This is from Aurora" & Assuming \\
\hline "I think this is such a hard question" & Concluding/stating \\
\hline S: "maybe meatball" & \\
T: "Oh...meatball, okay" & Concluding/stating \\
\hline S: "20" & \\
\hline
\end{tabular}

Apparently, from the teacher interview, the teacher admitted that her act of repeating students' answer was one of the efforts of listening. The nature of listening here is not "hearing"; rather, the teacher tried to show that she cared about what her students tried to say. In addition, being there for students and listening to what they say and their opinions are efforts of establishing a good rapport.

Harmer (2007) actually stated that building a good rapport, such as making students feel that the teacher treats them right, contributes to grow students' intrinsic motivation. Thus, when the motivation is there with the students, it encourages 
them more to pay attention and get actively involved in the teaching and learning process in the classroom.

\section{Expressive (6\%)}

39 utterances characterized by expressive speech act word clue are found in the data. Qadir and Riloff (2011) categorized utterances with expressive essence by signaling clues like thanking, apologizing, congratulating, condoling, deploring, appreciating, and welcoming. Among those 39 utterances, most expressive speech act uttered are listed below.

- "thank you",

- "I'm sorry", and

- "Oh my God!"

The utterance like "thank you" is always mentioned by the teacher after receiving things from the students or whenever her students try to remind her about something. "I'm sorry" is uttered when the teacher makes mistakes such as forgetting students' names or after making jokes that she thinks might hurt her students.

In the interview, she admitted that her reason of doing so is basically a habit because people are supposed to say "thank you" when somebody gives them something, say "sorry" if they think they might hurt somebody else's feeling, and say "oh my God" if people are surprised about something. The other reason is that the teacher wants to grow those basic habits in her students by being a good role model of a social human being. Therefore, the students will do the same when they interact inside or outside of the classroom.

\section{Directives (70\%)}

Directive speech acts dominate the utterance said by the teacher in the teaching process. Among those 673 utterances, $70 \%$ of them have directive speech acts word clues. Qadir and Riloff (2011) listed clues of directive speech act word. Utterances containing the force or intention to ask, order, command, request, beg, plead, pray, entreat, invite, permit, advise, dare, defy, and challenge, are categorized into directives. Mostly, the teacher used directives with the intention is to ask the students about something, and to command and request the students to do something. Some samples of directive speech acts uttered by the teacher are presented in Table 3.

Table 3. Directive Speech Act

\begin{tabular}{|c|c|c|}
\hline Utterance & $\begin{array}{l}\text { Directive } \\
\text { categories }\end{array}$ & act \\
\hline $\begin{array}{l}\text { "Uhmm... do you know, oh what is that?, other expression rather than saying } \\
\text { fine?" }\end{array}$ & Asking & \\
\hline "So can you please introduce yourself?" & Requesting & \\
\hline $\begin{array}{l}\text { "I want you to make two questions about me and also about person sitting } \\
\text { next to you" }\end{array}$ & Commanding & \\
\hline "you can have a sit Lintang" & Inviting & \\
\hline "Tell me, Lintang!" & Ordering & \\
\hline
\end{tabular}

Commissives

Commissive speech acts are the least mentioned by the teacher while teaching. The teacher only mentioned 19 utterances with commissive essence,
$(3 \%)$

which means the percentage is only $3 \%$ out of $100 \%$. Samples of commissive speech acts are listed in Table 4.

Table 4. Commissives Speech Act

\begin{tabular}{l}
\hline Utterance \\
\hline "Now, we are going to have a conversation, okay" \\
\hline "I am going to open this one first" \\
\hline "They'll believe it" \\
\hline "Okay guys, so we are going to have a break" \\
\hline "We are going to continue it again after the break."
\end{tabular}

The percentage of each speech act classification is drawn in Figure 1. It excludes declarative speech act as it does not exist in the data. To sum up, there are four speech acts classifications found in the study. They are representative/assertive, directive, expressive, and commissive. The dominant one used by the teacher is directive speech act which takes over $70 \%$ of the teacher's talk while doing the teaching. 


\section{Sri Meiweni Basra - Luthfiyatun Thoyyibah |A Speech Act Analysis of Teacher Talk in an EFL Classroom}

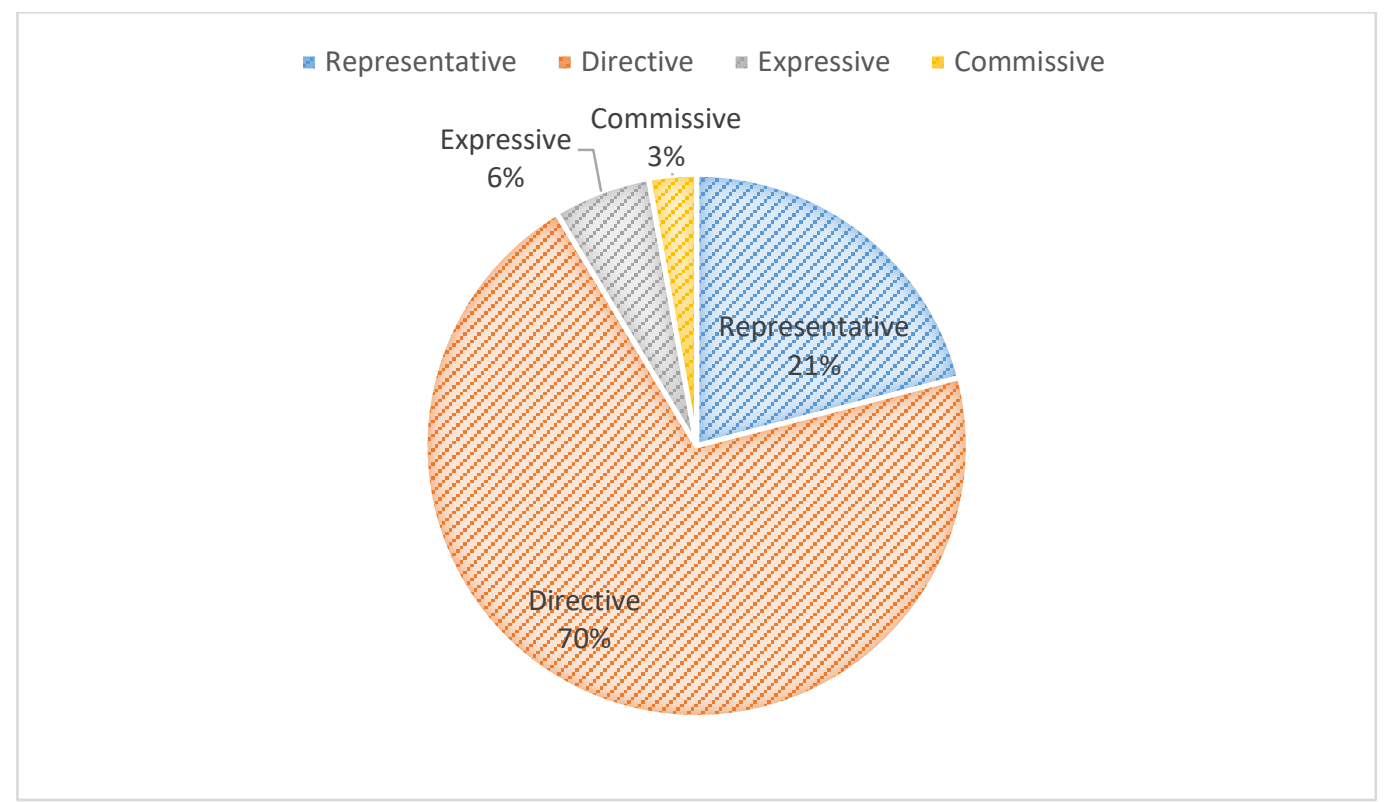

Figure 1. Percentages of Speech Acts Classification

The Teacher's Reasons of Using Directive Speech Act Dominantly

After carrying out teacher interview, it is found that the teacher does not really realize that she mostly used the directive speech acts while teaching. Below is the argument she pointed out related to her act in using directive speech act while teaching.

" The reason why I chose directive speech acts in my teaching is not because I know that it was directive speech acts. I didn't know that until you told me. So, uhm... okay, I used that because I really wanted my students to talk. I gave them chance to talk because, what is that? English is a means of communication. It means that you have to communicate it if it is not the language. So I really want my students to be active, not passive in speaking English. So, what is that?, by asking them a lot of questions, and then, what is that, and then...asking them also talk to their friends, I think it is the best way to teach English as a language. And then also, what else yah... uhm, it is because I also use this CLT (Communicative Language Teaching). It means that I just want my students to talk and uhm, and then also to give them a chance to think and then to express their own opinion. I just don't want to lecture all the time and then that one is not really studentscentered. So if it is students-centered it means that I have to give them the time as much as they need."

Therefore, there are two main reasons why the teacher unconsciously use directive speech acts. The first one is it is because the teacher carries the principle of CLT (Communicative Language Teaching) Approach. Richards (2006) defined CLT as an approach which highly values communicative competence rather than grammatical competence. It is because learners can learn the building blocks of sentences, but sometimes they are still not very successful in using language in a meaningful communication. Therefore, the exposure of communicative competence is the goal of CLT.

Second, the teacher wants to get students to be actively involved in the classroom activities. what the teacher is trying to do is getting them to talk by giving them chances through setting the classroom activities around the approach of CLT. The video (data) shows that the teacher organizes a class discussion and asks students to talk in pairs. Those activities characterize the approach of CLT. The activities fit what Richards (2006) pointed out in his book that activities carrying out the approach of CLT are the ones which have emphasis on pair or group work, and the ones with meaningful practice, in which the students are given the right to make meaningful choices when practicing.

The Implication towards either the Teaching Process or Students' Achievement that Can be Drawn from the Finding

Apparently, good communicative competence is the impact or the implication of using directive speech acts in the classroom as pointed out by Arani (2012). The study also reveals the same thing like Arani's that students achieve high scores, especially for two 
productive skills: speaking and writing. The class consisting of 14 students where the data of this study was taken has the average scores of $80 \%$ in speaking and $81 \%$ in writing. The scores prove that the use of directive speech act contributes in fostering students' productive skills, which also helps in building students' communicative competence.

\section{CONCLUSIONS AND RECOMMENDATION}

The use of appropriate speech act classification while teaching apparently is based on the teaching approach the teacher adopts. This study aims at investigating speech acts classification of teacher talk in EFL classrooms, the reason of the teacher uses certain speech acts, and the implication that can be drawn from the finding.

Based on the findings and discussion, four classifications of speech acts are found from the data (teacher talk). The total of the utterances uttered by the teacher in one meeting of teaching and learning is 673 utterances. Four classifications have different portions, with directive speech acts as the dominant one, taking over $70 \%$ of the utterances. The second dominant classification is representative speech act for $21 \%$. The expressive and commissive speech acts have small portions, namely $6 \%$ and $3 \%$, respectively.

The teacher argued that her reasons of using more directive speech acts are only to get students to talk more and to carry out the principle of Communicative Language Teaching as what she believes. The implication which can be drawn from the finding is that using directive speech acts which involves posing a lot of question, requesting, or commanding contribute to students' achievements, especially in productive skills. It is because by posing a lot of questions students are encouraged to answer the question and keep talking. Therefore, the choice of language and speech acts affects the teaching and learning as well as the teacher and students.

The recommendation is addressed for English teachers, especially in Indonesian context. Teaching Indonesian students a language which is foreign for them is not an easy task. Then, to expose them more to English, the classroom language instruction which is better to be used is English. However, teaching with foreign language instruction can cause trouble and misunderstanding between teacher and students. English teachers should realize soon their belief in teaching English. If the approach believed is CLT, then the speech act classification they need to use daily is directive speech act, which will engage students to talk more.

\section{References}

Akinwotu, S. A. (2013). A speech act analysis of the acceptance of nomination speeches of Chief Obafemi Awolowo and Chief M.K.O. Abiola. English Linguistic Research, 2(1), 44-51.

Arani, S. S. (2012). A study of directive speech acts used by Iranian nursery school children: The impact of context on children's linguistic choices. International Journal of Applied Linguistics \& English Literature, 1(5), 163175.

Austin, J.L. (1962). How to do things with words. Cambridge, Massachusetts: Harvard University Press

Celce-Murcia, M. (2000). Discourse and context in language teaching. Cambridge: Cambridge University Press.

Chiluwa, I. (2007). A speech act analysis of written adverts of soft drinks in Nigeria. Babcock Journal of Mass Communication, 1(3), 29-38.

Cohen, L., Manion, L., \& Morrison, K. (2007). Research methods in education. New York: Routledge.

Enyi, A. U. (2016). Rhetorical diplomacy: A study of Nigeria's President Muhammadu Buhari's speech to the $70^{\text {th }}$ Session of the United Nations General Assembly- September, 2015. British Journal of English Linguistics, 4(2), 38-52.

Enyi, A. U. (2016). Pragmatic analysis of Nigeria's President Mohammadu Buhari's Maiden Coup Address of January 1, 1984 and His Inaugural Address of May 29, 2015: A comparative appraisal. International Journal of English Language and Linguistics Research, 4(5), 47-64.

Grundy, P. (2008). Doing pragmatics $\left(3^{\text {rd }}\right)$ edition. London: Hodder Education.

Harmer, J. (2007). How to teach English. China: Pearson Education Limited.

Hashim, S. S. M. (2015). Speech acts in selected political speeches. International Journal of Humanities and Cultural Studies, 2(3), 396406.

llyas, S. \& Khushi, Q. (2012). Facebook status updates: A speech act analysis. Academic Research International 3(2), 500-507.

Introductory Guide to the Common European Framework of Reference for English Language Teachers. (2013). Cambridge University Press.

Lei, X. (2009). Communicative teacher talk in the English classroom. Journal of English Language Teaching, 2(1), 75-79.

Mey, J. (2001). Pragmatics: An introduction $\left(2^{\text {nd }}\right.$ edition). London: Blakewell.

Nurani, N. P. (2015). A pragmatic analysis of classroom speech acts in the English teaching and learning process at SMA N 1 Purworejo (A Case Study). (Unpublished Thesis). Yogyakarta State University, Indonesia.

Oluremi, Ajewole-Orimogunje C. (2016). Speech acts and Welfarist Ideology in Governor Aregbesola's May 1, 2013 Address. International Journal of English Language and Linguistics Research, 4(4), 23-32.

Qadir, A. ,\& Riloff, E. (2011). Classifying sentences as speech acts in message board posts. 


\section{Sri Meiweni Basra - Luthfiyatun Thoyyibah | A Speech Act Analysis of Teacher Talk in an EFL Classroom}

Proceedings of Empirical Methods in Natural Language Processing (EMNLP-2011), 748758.

Richards, Jack. C. (2006). Communicative language teaching today. New York: Cambridge University Press

Sadeghi, B., Ansari, F. J., \& Rahmani, R. (2015). The effect of teacher talk on EFL learners' language learning performance, and learning strategy use. International Journal of Language Learning and Applied Linguistics World (IJLLALW), 8(2), n.p.
Searle, J. R. (1976). A Classification of Illocutionary Acts. Language in Society, 5(1), 1-23.

Searle, J. R. (1999). Mind, language and society: Philosophy in the real world. Phoenix: Guernsey Press Co.

Seifoori, Z., \& Emadi, S. E. (2015). A Contrastive study of American and Persian compliment speech act. Modern Journal of Language Teaching Methods, 5(3),543-549.

Yule, G. (1996). Pragmatics. Oxford: OUP. 